\title{
Dietary sources of calcium and the contribution of flour fortification to total calcium intake in the diets of Northumbrian adolescents
}

\author{
BY PAULA MOYNIHAN, ASHLEY ADAMSON, ANDREW RUGG-GUNN, \\ DAVID APPLETON AND TIMOTHY BUTLER \\ Dental School, Medical Faculty, University of Newcastle upon Tyne, Framlington Place, \\ Newcastle upon Tyne NE2 $4 B W$
}

(Received 20 May 1994 - Revised 15 May 1995 - Accepted 9 June 1995)

\begin{abstract}
Increased $\mathrm{Ca}$ intake by adolescents is desirable. In order to achieve this, information on the current dietary sources of $\mathrm{Ca}$ by this age group is essential to enable change to build on existing habits. This paper addresses two issues: first, the dietary sources of $\mathrm{Ca}$ for adolescents are reported and, second, the importance of fortification of flour with Ca to present-day Ca intakes was determined. In 1990 the diets of 379 children aged 12 years were assessed using the $3 \mathrm{~d}$ dietary diary and interview method. Computerized food tables were used to calculate the contributions of different food groups to total $\mathbf{C a}$ intake. The $\mathrm{Ca}$ content of each food was subdivided into naturally occurring $\mathrm{Ca}$ and $\mathrm{Ca}$ from fortification, and data were analysed to give the daily intake of each. The four most important sources of Ca were milk $(25 \%)$, beverages $(12 \%)$, puddings $(10 \%)$ and bread $(9 \%)$. Fortification of flour accounted for $13 \%$ of total $\mathrm{Ca}$ intake. When the contribution of fortification was removed, the proportion of subjects with intakes of $\mathrm{Ca}$ below the lower reference nutrient intake (Department of Health, 1991) increased more than fourfold, to $10 \%$ of girls and $12 \%$ of boys. Milk is contributing less to $\mathrm{Ca}$ intake than in the past and increased consumption should be encouraged. Ca fortification of flour remains an important source of $\mathrm{Ca}$. Therefore, unless dietary habits are modified to ensure adequate $\mathrm{Ca}$ from other sources, increased consumption of unfortified products from outside the UK will lead to a further reduction in $\mathrm{Ca}$ intake.
\end{abstract}

Adolescents: Calcium: Fortification

The current epidemic of hip fractures in the UK costs the National Health Service about $\mathfrak{E} 600$ million each year (Kanis \& Pitt, 1992); therefore prevention of osteoporosis, its major cause, is an important health goal.

The main approach to the prevention of osteoporosis is to maximize peak bone mass (Stevenson et al. 1989). Intake of dietary Ca in adolescence (Sandler et al. 1985; Matkovic et al. 1990; Murphy et al. 1994) and adulthood (Ramsdale et al. 1994) is a critical factor in the development of peak bone mass. The adolescent growth spurt has been reported to be the time of maximum requirement for $\mathrm{Ca}$ (Garn, 1972). Studies have shown that intake of $\mathrm{Ca}$ by some British adolescents is inadequate (Department of Health, 1989; McNeill et al. 1991; Adamson et al. 1992). The Committee on Medical Aspects of Food Policy report The Diets of British Schoolchildren (Department of Health, 1989) reported mean values for $\mathrm{Ca}$ intake, for the 10-11-year-old children from the North of England, of $830 \mathrm{mg} / \mathrm{d}$ and $710 \mathrm{mg} / \mathrm{d}$ for boys and girls respectively; these values are below the reference nutrient intakes (RNI) of 1000 and $800 \mathrm{mg}$ for boys and girls respectively (Department of Health, 1991). 
In 1990 a nutritional survey of adolescents aged 11-12 years was carried out in Northumberland and the results were compared with those of a previous study carried out in 1980. The main findings have been published (Adamson et al. 1992). Intake of Ca decreased between 1980 and 1990 and the mean daily intakes for both boys $(786 \mathrm{mg} / \mathrm{d})$ and girls $(763 \mathrm{mg} / \mathrm{d}$ ) were below the RNI. This finding is supported by that of McNeill et al. (1991) who reported mean intakes of $\mathrm{Ca}$ by 12-year-olds in Scotland which were below the RNI. If an increase in Ca intake is to be promoted it is important to have information on current dietary sources of $\mathrm{Ca}$, to enable advice for change to build on existing dietary habits.

Existing reports of the dietary sources of $\mathrm{Ca}$ in British adolescent children are compiled from data over 10 years old. Information on the diets of British schoolchildren collected in 1983 (Department of Health, 1989) found the major contributors to Ca intake to be milk $(35 \%)$, bread $(11 \%)$, cheese $(9 \%)$ and puddings $(7 \%)$. Hackett et al. (1984), in the 1980 study of Northumbrian adolescents, found that the most important sources of dietary $\mathrm{Ca}$ were milk (49\%), Ca-fortified flour (16\%) and cheese (9\%). This study also found that Cafortification of flour made an important contribution to total $\mathrm{Ca}$ intake; without this contribution the proportion of children with $\mathrm{Ca}$ intakes below the recommended daily amount (RDA) of that time would have more than doubled.

Since 1942, all wheat flour (excluding wholemeal) has been fortified with $\mathrm{CaCO}_{3}$ to a level between 94 and $154 \mathrm{mg} \mathrm{Ca} / 100 \mathrm{~g}$ flour. This practice is mandatory in the UK and was initiated because of concern that food shortages of the war years, including the short supply of milk and cheese, would lead to the development of $\mathrm{Ca}$ deficiency in the population. Despite a Department of Health proposal in 1981 to curtail this practice (Department of Health and Social Security, 1981), flour is still fortified today, yet no data exist to show the importance of flour fortification in the 1990s.

The present paper considers two issues: first, it reports the sources of $\mathrm{Ca}$ in the diets of Northumbrian adolescents surveyed in 1990 and second, it highlights the importance of the contribution from flour fortification to total $\mathrm{Ca}$ intake.

\section{METHODS}

Between January and July 1990 a dietary survey of 379 Northumbrian adolescents aged 11-12 years was carried out in south Northumberland, locations being chosen to give a representative range of social classes. All children aged 11-12 years attending seven middle schools in this locality were invited to participate. The method and main findings of this survey have been published (Adamson et al. 1992). Briefly, each child recorded (in a specially designed diary) all food eaten for three consecutive days on two separate occasions. The child recorded the time of consumption and estimates, in household measures, of the quantities eaten. On the fourth day each child was interviewed by dietitian in order to clarify the information given. By questioning, with the aid of food models, a quantitative record of food intake was obtained (Hackett et al. 1983); colour photographs of the brands of selected foods were also available.

The food groups selected for the present analyses were as follows: (1) white bread; (2) wholemeal and brown bread; (3) bakery items (excluding bread), including biscuits, cakes, crackers, crumpets and muffins; (4) sweet puddings; (5) yoghurts; (6) ice cream; (7) skimmed and semi-skimmed milk including that in tea and coffee and on cereal but excluding milk used as an ingredient; (8) whole milk, including that in tea and coffee and on cereal but excluding milk used as an ingredient; (9) cheese, excluding that in baked dishes; (10) baked beans and vegetables, excluding potatoes; (11) chocolate, including fully coated biscuits, but excluding chocolate puddings and milk shakes; (12) milk shakes and 
hot milk drinks; (13) water, infusions of tea and coffee (excluding added milk) and soft drinks; (14) cheese and egg dishes, including quiches, pizza and macaroni cheese. The value of $\mathrm{Ca}$ content of water was $300 \mathrm{mg} / \mathrm{l}$ which was based on local information for the south Northumberland area.

Computerized food tables (Paul \& Southgate, 1978; Tan et al. 1985; Holland et al. 1988, 1989) together with purpose-written programs and Statistical Package for the Social Sciences (1986) were used to calculate the contributions of different food groups to total Ca intake. Analyses were carried out separately for each sex and by social class (Office of Population Censuses and Surveys, 1980). The level of significance of differences between sexes was tested using the Mann-Whitney $U$ test, and the statistical significance of social class trends was tested using parametric and non-parametric (Kruskal-Wallis) methods of ANOVA.

The value for $\mathrm{Ca}$ content of each food given in McCance and Widdowson's 'The Composition of Foods' (Paul \& Southgate, 1978) was subdivided into naturally occurring $\mathrm{Ca}$ and $\mathrm{Ca}$ from flour fortification. The value for the level of flour fortification used was $1250 \mathrm{mg} / \mathrm{kg}$ white flour which is that used in McCance and Widdowson's 'The Composition of Foods' (Paul \& Southgate, 1978; Holland et al. 1991) and is based on the Bread and Flour Regulations (1984) (as cited by Holland et al. 1991).

Where classification into naturally occurring $\mathrm{Ca}$ and $\mathrm{Ca}$ from fortification was not obvious, values were obtained by recipe inspection, and in some cases by food dissection. For example, chocolate-covered biscuits were dissected into chocolate and biscuit and each weighed, because the proportion of the product which was biscuit was required to calculate how much $\mathrm{Ca}$ was from fortification $(89.7 \%$ of the $\mathrm{Ca}$ present in the biscuit component only).

Because the mean intake of $\mathrm{Ca}$ for each subject was based on only a small number of days, the observed distribution of intakes was more variable than the true one. By estimating components of variance the reliability $(R)$ of the individual children's means could be calculated (Dunn, 1989) and used to find the standard deviation of the underlying distribution (Rugg-Gunn et al. 1987). This was done for each sex/social class subgroup in the study so that adjusted estimates could be made of the proportion of subjects in each subgroup with an intake of total $\mathrm{Ca}$ or natural $\mathrm{Ca}$ below the dietary reference values (DRV; Department of Health, 1991). For the lower reference nutrient intake (LRNI) adjusted proportions will always be lower than those observed. In an attempt to minimize the effect of distributional assumptions, the observed proportion $P_{\text {obs }}$, falling below a DRV was adjusted, rather than fitting a particular distribution to all of the data. We assumed normality in the tails and obtained $P_{c o r}=\Phi\left(\Phi^{-1}\left(P_{o b s}\right) / \sqrt{ } \mathrm{R}\right)$ where $\Phi$ is the cumulative normal distribution function. Typically the size of the adjustment made is comparable with the standard error of the estimate of the proportion.

For graphical comparison with the distribution assumed to calculate DRV we used lognormal distribution, which fitted the observed means well. For ANOVA we assumed normality of distributions; with the sample sizes involved and the small amount of skewness seen, this is justified by the central limit theorem, and when dealing with individual food groups avoids the problem of recording zeros for $\mathrm{Ca}$ intakes from particular sources. In any case the arithmetic mean intake is a more appropriate summary of intake than the geometric mean.

\section{RESULTS}

Of the 547 children invited to participate, 418 volunteered and 379 children $(91 \%$ of volunteers) completed all aspects of the study; of these, 195 were girls and 184 were boys. 
Table 1. The percentage contribution of different food groups to total calcium intake in 379 Northumbrian adolescents, calculated from the mean of $6 d$ per subject: analyses by sex

(Mean values with their standard errors, and ranges in parentheses)

\begin{tabular}{|c|c|c|c|c|c|c|c|}
\hline \multirow[b]{3}{*}{ Food group } & \multicolumn{6}{|c|}{ Percentage contribution to calcium intake } & \multirow[b]{3}{*}{$P$ value* } \\
\hline & \multicolumn{2}{|c|}{ Boys ( $n$ 184) } & \multicolumn{2}{|c|}{ Girls $(n$ 195) } & \multicolumn{2}{|c|}{ All children ( $n$ 379) } & \\
\hline & Mean & SEM (range) & Mean & SEM (range) & Mean & SEM (range) & \\
\hline \multicolumn{8}{|l|}{ Milk } \\
\hline Full fat & 15 & $1 \cdot 1(0-61)$ & 14 & $1 \cdot 0(0-51)$ & 14 & $0.8(0-61)$ & 0.086 \\
\hline $\begin{array}{l}\text { Skimmed/ } \\
\text { semi-skimmed }\end{array}$ & 13 & $1 \cdot 2(0-59)$ & 9 & $0.9(0-65)$ & 11 & $0 \cdot 7(0-65)$ & 0.02 \\
\hline All types & 28 & $0.9(0-60)$ & 23 & $0.9(0-65)$ & 25 & $0-68(0-66)$ & 0.001 \\
\hline \multicolumn{8}{|l|}{ Beverages } \\
\hline $\begin{array}{l}\text { Milk shakes } \\
\text { and hot milk } \\
\text { beverages }\end{array}$ & 4 & $0.5(0-34)$ & 4 & $0 \cdot 5(0-28)$ & 4 & $0 \cdot 3(0-34)$ & 0.48 \\
\hline Other beverages & 7 & $0.4(0-24)$ & 9 & $0.4(0.3-31)$ & 8 & $0 \cdot 3(0-31)$ & $<0.001$ \\
\hline All types & 11 & $0.5(0-46)$ & 13 & $0 \cdot 6(0 \cdot 3-38)$ & 12 & $0.4(0-46)$ & 0.049 \\
\hline \multicolumn{8}{|l|}{ Puddings } \\
\hline Sweet puddings & 4 & $0.4(0-21)$ & 4 & $0.4(0-27)$ & 4 & $0.3(0-27)$ & 0.95 \\
\hline Yoghurts & 3 & $0.4(0-26)$ & 4 & $0.4(0-29)$ & 3 & $0.3(0-29)$ & 0.011 \\
\hline Ice cream & 2 & $0 \cdot 2(0-18)$ & 2 & $0 \cdot 2(0-13)$ & 2 & $0 \cdot 2(0-18)$ & 0.74 \\
\hline All types & 9 & $0.5(0-34)$ & 10 & $0.6(0-48)$ & 10 & $0.4(0-48)$ & 0.11 \\
\hline \multicolumn{8}{|l|}{ Bread } \\
\hline White & 7 & $0.4(0-24)$ & 7 & $0.3(0-23)$ & 7 & $0.2(0-24)$ & 0.49 \\
\hline Wholemeal & 2 & $0.2(0-20)$ & 2 & $0.2(0-14)$ & 2 & $0.1(0-20)$ & 0.28 \\
\hline All types & 9 & $0.4(1-24)$ & 9 & $0 \cdot 3(0-24)$ & 9 & $0 \cdot 2(0-24)$ & 0.97 \\
\hline Cheese & 8 & $0.6(0-35)$ & 9 & $0-7(0-49)$ & 8 & $0-5(0-49)$ & 0.036 \\
\hline Chocolate & 5 & $0.4(0-27)$ & 6 & $0.3(0-20)$ & 5 & $0.2(0-27)$ & 0.11 \\
\hline Bakery items & 5 & $0.3(0-16)$ & 6 & $0 \cdot 3(0-20)$ & 5 & $0 \cdot 2(0-20)$ & 0.098 \\
\hline $\begin{array}{l}\text { Cheese and egg } \\
\text { dishes }\end{array}$ & 3 & $0.4(0-32)$ & 4 & $0 \cdot 4(0-27)$ & 4 & $0 \cdot 3(0-32)$ & $0 \cdot 11$ \\
\hline $\begin{array}{l}\text { Baked beans and } \\
\text { vegetables }\end{array}$ & 3 & $0 \cdot 2(0-15)$ & 3 & $0.2(0-16)$ & 3 & $0 \cdot 1(0-16)$ & 0.79 \\
\hline Other sources & 19 & $0 \cdot 6(5-53)$ & 18 & $0.5(5-45)$ & 19 & $0 \cdot 4(5-53)$ & 0.12 \\
\hline $\begin{array}{l}\text { Total calcium } \\
\text { intake (mg) }\end{array}$ & 786 & $19(304-2251)$ & 763 & $16(320-1560)$ & 774 & $12(304-2251)$ & 0.54 \\
\hline
\end{tabular}

* $P$ values calculated on 323 children, adjusted for social class. Means quoted use all 379 children (fifty-six children did not fall into the defined social class groupings).

The contributions of the food groups to the total $\mathrm{Ca}$ intake are presented in Tables 1 and 2. Values are presented for each sex separately and for the group as a whole (Table 1) and by social class (Table 2). Values represent the percentage contribution from each food group and the total $\mathrm{Ca}$ intake is given on the last line of the tables. Those subjects who did not fall into the defined social class criteria ( $n$ 56) were excluded from the analysis by social class, therefore the values reported in Table 2 refer to 323 subjects. Social class analysis took into account sex differences between social class groups. ANOVA was by sex accounting for social class; therefore, although the mean values presented in Table 1 are for 184 boys and 195 girls, the $P$ values were calculated using the 323 subjects who fell into the defined social class criteria. 
Table 2. The percentage contribution of different food groups to total calcium intake in 323 Northumbrian adolescents, calculated from the mean of $6 d$ per subject: analyses by social class*

(Mean values with their standard errors, and ranges in parentheses)

\begin{tabular}{|c|c|c|c|c|c|c|c|}
\hline \multirow[b]{3}{*}{ Food group } & \multicolumn{6}{|c|}{ Percentage contribution to calcium intake } & \multirow[b]{3}{*}{$P$ valuef } \\
\hline & \multicolumn{2}{|c|}{ High ( $n$ 137) } & \multicolumn{2}{|c|}{ Middle ( $n$ 116) } & \multicolumn{2}{|c|}{ Low $(n 70)$} & \\
\hline & Mean & SEM (range) & Mean & SEM (range) & Mean & SEM (range) & \\
\hline \multicolumn{8}{|l|}{ Milk } \\
\hline Full fat & 11 & $1.3(0-56)$ & 14 & $1 \cdot 2(0-61)$ & 17 & $1 \cdot 7(0-47)$ & 0.012 \\
\hline $\begin{array}{l}\text { Skimmed/ } \\
\text { semi-skimmed }\end{array}$ & 14 & $1 \cdot 3(0-59)$ & 12 & $1 \cdot 3(0-62)$ & 9 & $1.8(0-65)$ & 0.02 \\
\hline All types & 25 & $1 \cdot 2(0-59)$ & 25 & $1 \cdot 2(0-66)$ & 25 & $1.6(0-65)$ & 0.91 \\
\hline \multicolumn{8}{|l|}{ Beverages } \\
\hline $\begin{array}{l}\text { Milk shakes } \\
\text { and hot milk } \\
\text { beverages }\end{array}$ & 4 & $0.6(0-34)$ & 4 & $0.6(0-29)$ & 4 & $0.6(0-19)$ & 0.91 \\
\hline Other beverages & 9 & $0.5(0-31)$ & 8 & $0.5(1-26)$ & 7 & $0.6(0-31)$ & 0.081 \\
\hline All types & 12 & $0.7(0-46)$ & 11 & $0.7(1-38)$ & 11 & $0.8(0-31)$ & 0.22 \\
\hline \multicolumn{8}{|l|}{ Puddings } \\
\hline Sweet puddings & 4 & $0.4(0-20)$ & 4 & $0.5(0-21)$ & 4 & $0.6(0-27)$ & 0.72 \\
\hline Yoghurts & 4 & $0.5(0-29)$ & 3 & $0.5(0-24)$ & 3 & $0.5(0-17)$ & 0.061 \\
\hline Ice cream & 2 & $0.3(0-18)$ & 2 & $0.3(0-13)$ & 2 & $0.3(0-18)$ & 0.13 \\
\hline All types & 11 & $0.7(0-48)$ & 10 & $0.7(0-40)$ & 8 & $0.8(0-28)$ & 0.035 \\
\hline \multicolumn{8}{|l|}{ Bread } \\
\hline White & 6 & $0.4(0-16)$ & 7 & $0.5(0-23)$ & 8 & $0 \cdot 6(0-24)$ & 0.001 \\
\hline Wholemeal & 3 & $0.2(0-14)$ & 2 & $0 \cdot 3(0-20)$ & 2 & $0.3(0-14)$ & 0.019 \\
\hline All types & 8 & $0.4(1-21)$ & 9 & $0.5(1-24)$ & 10 & $0.6(0-24)$ & 0.056 \\
\hline Cheese & 9 & $0 \cdot 8(0-46)$ & 8 & $0 \cdot 8(0-49)$ & 9 & $1 \cdot 2(0-49)$ & 0.93 \\
\hline Chocolate & 5 & $0.3(0-17)$ & 6 & $0.4(0-27)$ & 6 & $0.5(0-19)$ & 0.01 \\
\hline Bakery items & 5 & $0.3(0-16)$ & 5 & $0.3(0-16)$ & 5 & $0.4(0-15)$ & 0.89 \\
\hline $\begin{array}{l}\text { Cheese and egg } \\
\text { dishes }\end{array}$ & 5 & $0.6(0-32)$ & 3 & $0.4(0-17)$ & 3 & $0.5(0-17)$ & 0.015 \\
\hline $\begin{array}{l}\text { Baked beans and } \\
\text { vegetables }\end{array}$ & 3 & $0 \cdot 2(0-16)$ & 3 & $0.2(0-15)$ & 3 & $0 \cdot 3(0-11)$ & 0.42 \\
\hline Other sources & 16 & $0.6(4-45)$ & 11 & $0.7(5-53)$ & 18 & $0.8(7-40)$ & 0.035 \\
\hline
\end{tabular}

* Social class according to Office of Population Censuses and Surveys (1980): I and II, high, III, middle; IV and $\mathrm{V}$, low.

$\dagger P$ values adjusted for sex.

The four most important sources of $\mathrm{Ca}$, for the group as a whole, were: milk (excluding milk as an ingredient) $(25 \%)$; beverages (12\%); puddings $(10 \%)$ and bread $(9 \%)$. Cheese contributed $8 \%$ of total $\mathrm{Ca}$ intake. When the beverages food group was subdivided into milk shakes/hot milk beverages and non-milk-based beverages, non-milk beverages (i.e. water, tea and coffee infusions) provided $8 \%$ of total $\mathrm{Ca}$ intake. Smaller contributions were provided by chocolate $(5 \%)$, bakery items $(5 \%)$, cheese and egg dishes $(4 \%)$ and vegetables $(3 \%)$. Only minor differences in rank order of importance of different food sources to total $\mathrm{Ca}$ intake existed between boys and girls (Table 1). Boys obtained significantly more Ca from milk $(P<0.0001)$ and girls obtained significantly more Ca from non-milk beverages $(P<0.049)$. Girls also obtained more Ca from yoghurts $(P=0.01)$ and cheese $(P=0.036)$. Statistically significant social class trends were observed for percentage 
Table 3. Intake of calcium with and without the contribution from flour fortification by 11-12year-old adolescents, calculated from the mean of 6 d per subject: analysis by sex and social class*

(Mean values with their standard errors)

\begin{tabular}{|c|c|c|c|c|c|c|c|}
\hline & \multirow[b]{3}{*}{$n$} & \multicolumn{6}{|c|}{ Calcium intake (mg/d) } \\
\hline & & \multicolumn{2}{|c|}{$\begin{array}{c}\text { With } \\
\text { fortification }\end{array}$} & \multicolumn{2}{|c|}{$\begin{array}{c}\text { Without } \\
\text { fortification }\end{array}$} & \multicolumn{2}{|c|}{$\begin{array}{l}\text { Calcium from } \\
\text { fortification }\end{array}$} \\
\hline & & Mean & $\mathbf{S E}$ & Mean & SE & Mean & SE \\
\hline All & 379 & 774 & 12 & 672 & 12 & 102 & 2 \\
\hline \multicolumn{8}{|l|}{ Boys } \\
\hline All & 184 & 786 & 19 & 682 & 18 & 104 & 3 \\
\hline High & 70 & 818 & 32 & 713 & 29 & 105 & 6 \\
\hline Middle & 56 & 808 & 14 & 711 & 40 & 97 & 5 \\
\hline Low & 32 & 758 & 32 & 645 & 30 & 113 & 7 \\
\hline \multicolumn{8}{|l|}{ Girls } \\
\hline All & 195 & 763 & 16 & 663 & 16 & 100 & 3 \\
\hline High & 67 & 787 & 31 & 689 & 31 & 98 & 5 \\
\hline Middle & 60 & 739 & 26 & 638 & 24 & 101 & 5 \\
\hline Low & 38 & 744 & 33 & 644 & 33 & 100 & 5 \\
\hline
\end{tabular}

* Social class according to Office of Population Censuses and Surveys (1980): I and II, high; III, middle; IV and $\mathrm{V}$, low.

of Ca from skimmed and semi-skimmed milk $(P=0.02)$, puddings $(P=0.035)$, cheese and egg dishes $(P=0.015)$ and wholemeal bread $(P=0.019)$ in the direction of a decreased contribution with decreasing social class group (high $\rightarrow$ lower). Food groups which showed an increasing contribution to total $\mathrm{Ca}$ intake with decreasing social class included full-fat milk $(P=0.012)$, white bread $(P=0.001)$ and chocolate $(P=0.01)$. Social class trends which did not quite reach statistical significance included a reduced contribution to $\mathrm{Ca}$ intake by non-milk beverages and yoghurts and an increased contribution to $\mathrm{Ca}$ intake by bread (all types) with decreasing social class.

Mean daily intakes of total $\mathrm{Ca}$, naturally occurring $\mathrm{Ca}$ and $\mathrm{Ca}$ from fortification are presented in Table 3. For the group as a whole, Ca-fortification of flour contributed $13 \%$ of the total $\mathrm{Ca}$ intake.

Fig. 1 compares the frequency distribution of total $\mathrm{Ca}$ intake and naturally occurring $\mathrm{Ca}$ intake for both the boys (a) and the girls (b) with the DRV curves, and illustrates the proportion of the study population that falls short of these guidelines. Removal of $\mathrm{Ca}$ supplied by fortification has a marked effect on the frequency distribution of intake, especially at the lower end of the distribution curve. The proportions of boys and girls with intakes of total and naturally occurring Ca below the DRV are presented in Table 4 . For total $\mathrm{Ca}, 2 \%$ of girls and $3 \%$ of boys were below the LRNI (the amount thought to be sufficient for only $2.5 \%$ of the population). These figures increased fourfold or more to 10 and $12 \%$ for girls and boys respectively, when the contribution of fortification was removed. Statistical analyses indicated no significant social class trend in the proportion of subjects from each social class group who had natural $\mathrm{Ca}$ intakes below the LRNI.

On the basis of the present findings, the average level of fortification necessary to bring $97.5 \%$ of subjects above the LRNI was calculated to be $2030 \mathrm{mg} \mathrm{Ca} / \mathrm{kg}$ flour for boys and 

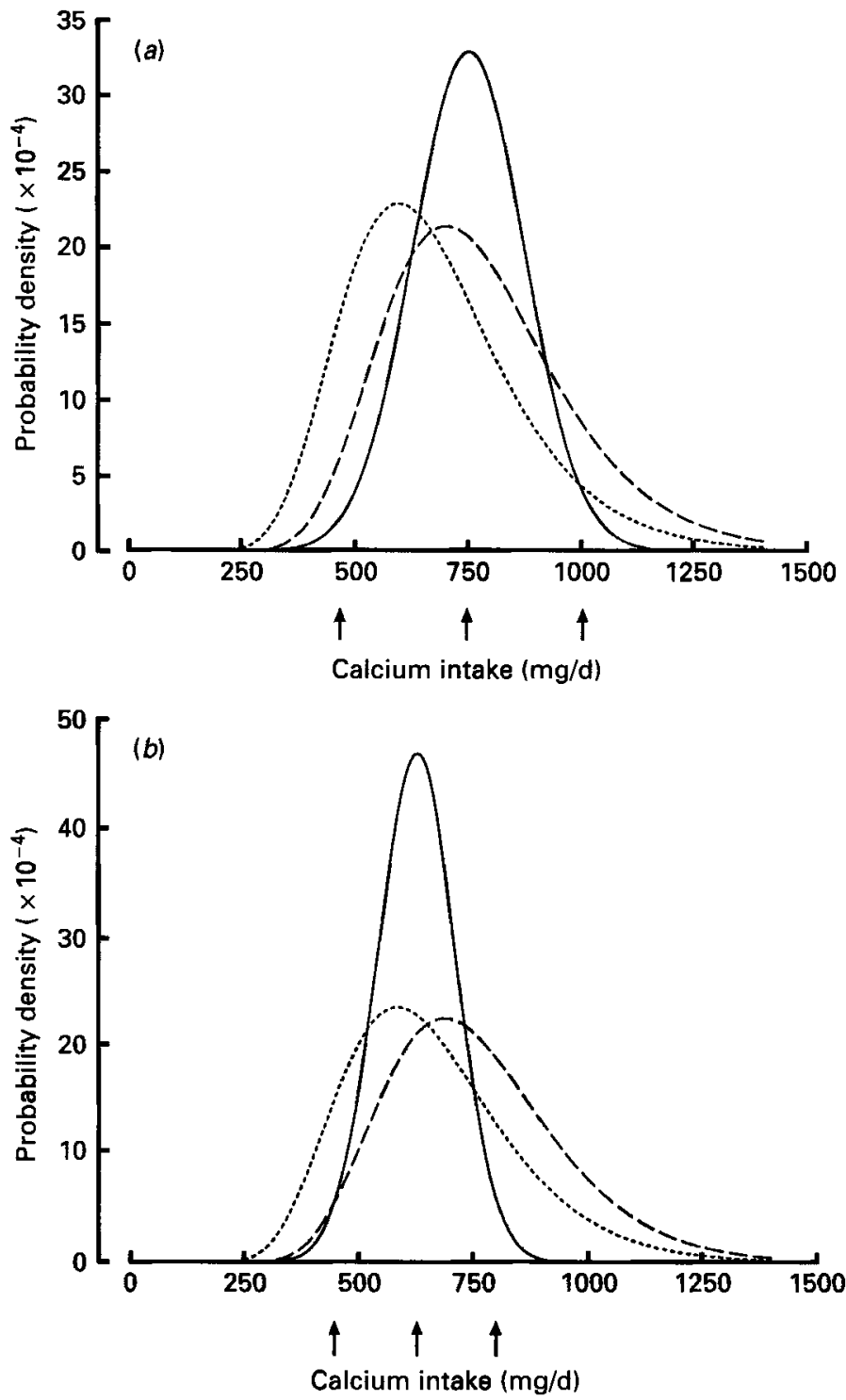

Fig. 1. Percentage frequency distribution of mean calcium intake (adjusted values) for (a) boys and (b) girls with $(--)$ and without (---) fortification. The continuous curve $(-)$ is the normal distribution of requirements (Department of Health, 1991) and the solid arrows indicate (left to right) the lower reference nutrient intake, estimated average requirement and reference nutrient intake for calcium for this age group and sex.

$1880 \mathrm{mg} / \mathrm{kg}$ flour for girls. These estimates were calculated assuming a log-normal distribution for the $\mathrm{Ca}$ intake. Calculations for these estimates were also carried out using the observed second centiles of the distributions. This produced similar results suggesting the suitability of the log-normal assumption. 
Table 4. Percentage of subjects (adjusted data) with daily intakes of naturally occurring calcium and total calcium below the lower reference nutrient intake (LRNI), estimated average requirement $(E A R)$ and reference nutrient intake ( $R N I)$ (Department of Health, 1991): analysis by sex and social class*

\begin{tabular}{|c|c|c|c|c|c|c|c|}
\hline & \multirow[b]{2}{*}{$n$} & \multicolumn{2}{|c|}{$\begin{array}{c}\text { LRNI } \\
\text { Fortification }\end{array}$} & \multicolumn{2}{|c|}{$\begin{array}{c}\text { EAR } \\
\text { Fortification }\end{array}$} & \multicolumn{2}{|c|}{$\begin{array}{c}\text { RNI } \\
\text { Fortification }\end{array}$} \\
\hline & & With & Without & With & Without & With & Without \\
\hline \multicolumn{8}{|l|}{ Boys } \\
\hline All & 184 & 3 & 12 & 54 & 74 & 86 & 95 \\
\hline High & 70 & 3 & 16 & 47 & 63 & 81 & 91 \\
\hline Middle & 56 & 4 & 6 & 52 & 72 & 83 & 94 \\
\hline Low & 32 & 0 & 11 & 59 & 89 & 95 & 100 \\
\hline \multicolumn{8}{|l|}{ Girls } \\
\hline All & 195 & 2 & 10 & 22 & 48 & 69 & 82 \\
\hline High & 67 & 3 & 10 & 22 & 47 & 65 & 76 \\
\hline Middle & 60 & 0 & 7 & 18 & 55 & 78 & 92 \\
\hline Low & 38 & 1 & 15 & 26 & 43 & 68 & 90 \\
\hline
\end{tabular}

* Social class according to Office of Population Censuses and Surveys (1980): I and II, high; III, middle; IV and $\mathrm{V}$, low.

\section{DISCUSSION}

The present paper illustrates how, when comparing the distribution of intake of study populations to the dietary reference distribution, the theoretical average of the intake of each subject over an infinite number of days should be used and not the mean intake of the number of days studied.

The potential error in using the observed data is illustrated in Fig. 2 which shows the distribution of total $\mathrm{Ca}$ intake in girls. The unadjusted proportion of girls with total $\mathrm{Ca}$ intake below the LRNI was $6 \%$, compared with $2 \%$ in the adjusted distribution, the value reported in Table 4.

The aims of the present paper were to report the contributions of various food groups to total $\mathrm{Ca}$ intake and to investigate the contribution of $\mathrm{Ca}$ fortification of flour to total dietary $\mathrm{Ca}$ intake. The present analysis was subsidiary to a comprehensive investigation of diet and nutrient intake of Northumbrian adolescents (Adamson et al. 1992). The validity and reliability of the dietary assessment method used have been discussed previously (Hackett et al. 1983; Adamson et al. 1992).

Comparison between studies is complicated due to variation in food group definitions. With respect to the contribution of dairy products to $\mathrm{Ca}$ intake, the present findings are similar to those of McNeill et al. (1991) who, in a study of Scottish children, found that contributions from dairy products and eggs provided $49 \%$ of $\mathrm{Ca}$ intake. This compares with the present study where the contributions from milk, milk shakes and hot beverages, yoghurt, cheese, and cheese and egg dishes together provided $45 \%$ of $\mathrm{Ca}$ intake. The value obtained for the contribution of milk to Ca intake is much lower than that reported in The Diets of British Schoolchildren (Department of Health, 1989) of $35 \%$. This may be because the Department of Health (1989) value possibly included milk as an ingredient in addition to pure milk. The analysis of dietary sources of $\mathrm{Ca}$ obtained from the 1980 survey of Northumbrian adolescents was less comprehensive than the present analysis and only considered three sources of dietary Ca: milk, cheese and fortification of flour. Nonetheless 


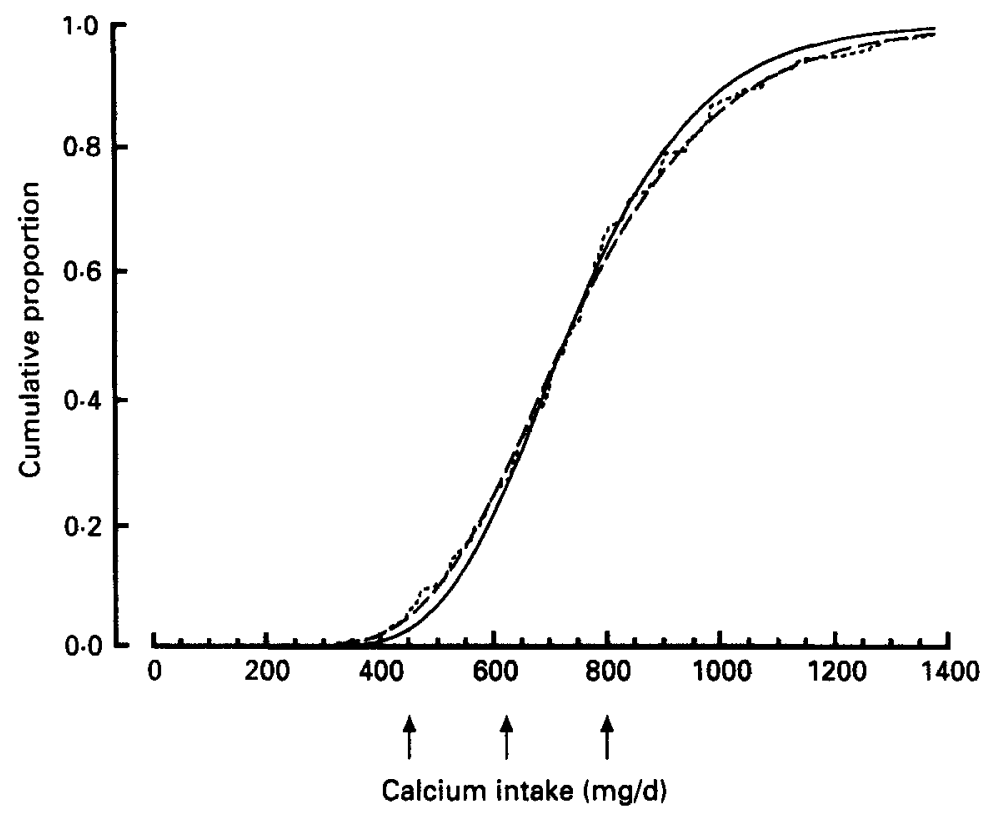

Fig. 2. The cumulative distribution of total calcium intake for 195 girls. (---), Observed distribution; (---), best fit log-normal distribution; (-), theoretically adjusted best fit representing the true between-children distribution. The arrows indicate (left to right) the lower reference mutrient intake, estimated average requirement and reference nutrient intake for calcium for this age group and sex (Department of Health, 1991).

the 1980 survey showed that milk (including milk shakes and hot milk drinks) contributed $48 \%$ to total Ca intake, which is greater than the value obtained in 1990 of $29 \%$ for milk including milk shakes and hot milk drinks. Data from the National Food Surveys indicate a downward trend in milk consumption between 1983 and 1990 for the population as a whole from 4.43 to 3.82 pints/week (Ministry of Agriculture, Fisheries and Food, 1985, $1986,1989,1992)$. It is possible that this decline may be greater in adolescents. This observation is of particular concern since it has recently been reported that frequent milk consumption before the age of 25 years positively influences hip bone mass in middle and older age (Murphy et al. 1994). The observation that girls obtained significantly less Ca from milk than boys has been reported previously (Hackett et al. 1984; Department of Health, 1989). Data from the present study have shown that this is to some extent compensated for by greater contributions of non-milk beverages, yoghurts and chocolate to total $\mathrm{Ca}$ intake. The contribution of non-milk beverages to total $\mathrm{Ca}$ intake was substantial and was largely due to $\mathrm{Ca}$ present in water. The contribution made by water to total $\mathrm{Ca}$ intake will show geographical variation according to the hardness of water. In the South Northumbrian area the water $\mathrm{Ca}$ concentration is $300 \mathrm{mg} / \mathrm{l}$.

The contribution of cheese to total $\mathrm{Ca}$ intake seems to have changed very little over the period of 10 years. In the 1980 survey Hackett et al. (1984) reported that cheese contributed $9 \%$ to total $\mathrm{Ca}$ intake. The present study found that cheese contributed $8 \%$ to total $\mathrm{Ca}$ intake which is the same as the value obtained in the Department of Health (1989) report of the diets of British schoolchildren.

In the present study the contribution made by bread to total Ca intake (9\%) was below the figure reported in The Diets of British Schoolchildren (Department of Health, 1989) $(11 \%)$ and the value reported by McNeill et al. (1991) for Ca from bread (11\%). 
$\mathrm{Ca}$ fortification of white flour accounted for $13 \%$ of total $\mathrm{Ca}$ intake. This value was lower than the value of $16 \%$ reported in the 1980 survey (Hackett et al. 1984). A reduction in consumption of white bread may have contributed to this downward trend. Data from the two surveys show a fall in the consumption of white bread between 1980 and 1990 (A. Adamson, A. Rugg-Gunn, T. Butler and D. Appleton, unpublished results). This is in agreement with National Food Surveys which have shown a decreasing trend in the consumption of white bread during the past decade (Ministry of Agriculture, Fisheries and Food, 1985, 1986, 1989, 1992). The fact that wholemeal breads are being promoted may account, in part, for the decrease in $\mathrm{Ca}$ intake that was observed between 1980 and 1990 (Adamson et al. 1992). Wholemeal bread on average contains half the $\mathrm{Ca}$ of white bread (Holland et al. 1991). This observation highlights the impact that changing one aspect of the diet has on another. If consumption of wholemeal breads is to be encouraged, advice to increase Ca consumption from other dietary sources is essential, especially in the lower social classes who obtain significantly more of their $\mathrm{Ca}$ from this source than the higher social classes.

The current guidelines for Ca intake in the UK are the DRV (Department of Health, 1991), which are age- and sex-specific. The estimated average requirements (EAR) for Ca were set using information on retention and absorption. The EAR is the amount of dietary Ca thought to provide for mean daily retention, assuming $40 \%$ net absorption of $\mathrm{Ca}$. The RNI are based on the EAR by adding two notional standard deviations, and are thought to be adequate for $97.5 \%$ of the population. The LRNI are set at two notional standard deviations below the EAR, and are thought to be adequate for only $2.5 \%$ of the population. These values are yardsticks by which the adequacy of intake of a given population can be judged.

The findings of the present study suggest that if flour fortification were to cease, the proportion of adolescents with intakes of $\mathrm{Ca}$ below the LRNI could increase at least fourfold to as great as $16 \%$. In the present study the detrimental effect of removing fortification on $\mathrm{Ca}$ intake was less obvious when intakes of natural $\mathrm{Ca}$ were compared to the upper end of the DRV range (RNI) and this is clearly illustrated in Fig. 1. Although the proportion of subjects in each category who fell below the RNI was greater when the contribution of fortification was excluded, comparing the intakes of natural $\mathrm{Ca}$ to the RNI does not identify the population at risk. Comparison with the RNI alone may mask what is happening at the lower end of the intake range. This observation suggests that previous reports (eg. Ministry of Agriculture, Fisheries and Food, 1986) which have judged the adequacy of $\mathrm{Ca}$ intake, without and with fortification, by comparison with the RDA (Department of Health and Social Security, 1979), may have underestimated the adverse effect of removal of $\mathrm{CaCo}_{3}$ from flour.

The UK is the only member of the European Union in which fortification of flour with $\mathrm{Ca}$ is mandatory. Data presented here would support strongly that this fortification is continued until such time that dietary intakes change to ensure an adequacy of naturallyoccurring $\mathrm{Ca}$. With increasing free trade between countries of the European Union the consumption of unfortified flour-containing products from countries outside the UK is inevitable, and may lead to a further reduction in Ca intake of the UK population. In view of this, and the association between $\mathrm{Ca}$ intake and osteoporosis, nutrition health education aimed at promoting consumption of Ca-rich foods (preferably low-fat varieties) becomes an essential public health goal.

This study was funded by the Medical Research Council and Newcastle Health Authority. The authors acknowledge, with gratitude, the assistance of Northumberland Health and Education Authorities, the schools, children and parents involved. 


\section{REFERENCES}

Adamson, A. J., Rugg-Gunn, A. J., Butler, T. J., Appleton, D. R. \& Hackett, A. F. (1992). Nutritional intake, height and weight of 11-12-year-old Northumbrian children in 1990 compared with information obtained in 1980. British Journal of Nutrition 68, 543-563.

Bread and Flour Regulations (1984). Statutory Instrument no. 1304. London: H.M. Stationery Office.

Department of Health (1989). The Diets of British Schoolchildren. Report on Health and Social Subjects no. 36. London: H.M. Stationery Office.

Department of Health (1991). Dietary Reference Values for Food Energy and Nutrients for the United Kingdom. Report on Health and Social Subjects no. 41. London: H.M. Stationery Office.

Department of Health and Social Security (1981). Nutritional Aspects of Bread and Flour. Report on Health and Social Subjects no. 23. London: H.M. Stationery Office.

Dunn, G. (1989). Design and Analysis of Reliability Studies. London: Edward Arnold.

Garn, S. M. (1972). The course of bone gain and the phases of bone loss. Orthopedic Clinics of North America 3, $503-520$.

Hackett, A. F., Rugg-Gunn, A. J., Allinson, M., Robinson, C. J., Appleton, D. R. \& Eastoe, J. E. (1984). The importance of fortification of flour with calcium and the sources of $\mathrm{Ca}$ in the diet of 375 English adolescents. British Journal of Nutrition 51, 193-197.

Hackett, A. F., Rugg-Gunn, A. J. \& Appleton, D. R. (1983). The use of a dietary diary and interview to estimate the food intake of children. Human Nutrition: Applied Nutrition 37A, 293-300.

Holland, B., Unwin, I. D. \& Buss, D. H. (1988). Cereals and Cereal Products. The Third Supplement to McCance and Widdowson's 'The Composition of Foods', 4th ed. London: The Royal Society of Chemistry and Ministry of Agriculture, Fisheries and Food.

Holland, B., Unwin, I. D. \& Buss, D. H. (1989). Milk Products and Eggs. The Fourth Supplement to McCance and Widdowson's 'The Composition of Foods', 4th ed. London: The Royal Society of Chemistry and Ministry of Agriculture, Fisheries and Food.

Holland, B., Welch, A. A., Unwin, I. D., Buss, D. H., Paul, A. A. \& Southgate, D. A. T. (1991). McCance and Widdowson's 'The Composition of Foods', 5 th ed. Cambridge: The Royal Society of Chemistry and Ministry of Agriculture, Fisheries and Food.

Kanis, J. A. \& Pitt, F. A. (1992). Epidemiology of osteoporosis. Bone 13, S7-S15.

McNeill, G., Davidson, L., Morrison, D. C., Crombie, I. K., Keighran, J. \& Todman, J. (1991). Nutrient intake in schoolchildren: some practical considerations. Proceedings of the Nutrition Society 50, 37-43.

Matkovic, V., Fontana, D., Tominac, C., Goel, P. \& Chesnut, C. H. (1990). Factors that influence peak bone mass formation: a study of calcium balance and the inheritance of bone mass in adolescent females. American Journal of Clinical Nutrition 52, 878-888.

Ministry of Agriculture, Fisheries and Food (1985). Household Food Consumption and Expenditure 1985: Annual Report of the National Food Survey Committee. London: H.M. Stationery Office.

Ministry of Agriculture, Fisheries and Food (1986). Household Food Consumption and Expenditure 1986: Annual Report of the National Food Survey Committee. London: H.M. Stationery Office.

Ministry of Agriculture, Fisheries and Food (1989). Household Food Consumption and Expenditure 1989: Annual Report of the National Food Survey Committee. London: H.M. Stationery Office.

Ministry of Agriculture, Fisheries and Food (1992). Household Food Consumption and Expenditure 1992: Annual Report of the National Food Survey Committee. London: H.M. Stationery Office.

Murphy, S., Khaw, K., May, H. \& Compston, J. E. (1994). Milk consumption and bone mineral density in middle aged and elderly women. British Medical Journal 308, 939-941.

Office of Population Censuses and Surveys (1980). Classification of Occupations. London: H.M. Stationery Office.

Paul, A. A. \& Southgate, D. A. T. (1978). McCance and Widdowson's 'The Composition of Foods', 4th ed. London: H.M. Stationery Office.

Ramsdale, S. J., Bassey, E. J. \& Pye, D. J. (1994). Dietary calcium intake relates to bone mineral density in premenopausal women. British Journal of Nutrition 71, 77-84.

Rugg-Gunn, A. J., Hackett, A. F., Appleton, D. R., Eastoe, J. E., Dowthwaite, L. \& Wright, W. G. (1987). The water intake of 405 Northumberland adolescents aged 12-14 years. British Dental Journal 162, 335-340.

Sandler, R. B., Slemenda, C. W., LaPorte, R. E., Cauley, J. A., Schramm, M. M., Barresi, M. L. \& Kriska, A. M. (1985). Postmenopausal bone density and milk consumption in childhood and adolescence. American Journal of Clinical Nutrition 42, 270-274.

Statistical Package for the Social Sciences (1986). SPSSx User's Guide, 2nd ed. Chicago, Illinois: SPSS Inc.

Stevenson, J. C., Lees, B., Devenport, M., Cust, M. P. \& Ganger, K. F. (1989). Determinants of bone density in normal women: risk factors for future osteoporosis? British Medical Journal 298, 924-927.

Tan, S. P., Wenlock, R. W. \& Buss, D. H. (1985). Immigrant Foods, Second Supplement to McCance and Widdowson's 'The Composition of Foods'. London: H.M. Stationery Office. 